\title{
Immunohistochemical demonstration of the zinc metalloprotease insulin-degrading enzyme in normal and malignant human breast: Correlation with tissue insulin levels
}

\author{
RAZVAN T. RADULESCU ${ }^{1}$, CARLA HUFNAGEL ${ }^{1}$, PETER LUPPA $^{2}$, HEIDE HELLEBRAND $^{3}$, \\ WEN-LIANG KUO ${ }^{4}$, MARSHA RICH ROSNER ${ }^{4}$, NADIA HARBECK ${ }^{1}$, CECYLIA GIERSIG $^{5}$, \\ ALFONS MEINDL ${ }^{3}$, MANFRED SCHMITT $^{1}$ and GREGOR WEIRICH ${ }^{6}$
}

\author{
${ }^{1}$ Clinical Research Unit, Department of Obstetrics and Gynecology, ${ }^{2}$ Department of Clinical Chemistry, \\ ${ }^{3}$ Tumor Genetics Unit, Department of Gynecology and Obstetrics, Klinikum rechts der Isar, \\ Technical University of Munich, Ismaninger Str. 22, D-81675 Munich, Germany; ${ }^{4}$ Ben May Institute for \\ Cancer Research, Center for Integrative Sciences, 929 East 57th Street, W421, Chicago, IL 60637, USA; \\ ${ }^{5}$ Federal Institute for Drugs and Medical Devices, Kurt-Georg-Kiesinger-Allee 3, D-53175 Bonn, \\ ${ }^{6}$ Institute of Pathology, Technical University of Munich, Ismaninger Str. 22, D-81675 Munich, Germany
}

Received July 28, 2006; Accepted September 20, 2006

\begin{abstract}
Insulin is a hormone crucial to metabolism and an essential growth factor for normal and neoplastic tissues. We have now determined insulin in extracts of 23 primary breast cancer specimens and of non-neoplastic breast tissues by a chemiluminescent immunoassay. Remarkably, insulin was measured only in grade 3 tumors, whereas grade 2 carcinomas and the normal mammary gland were each insulin-negative. We also performed immunohistochemistry for insulin-degrading enzyme (IDE), a cytoplasmic zinc metalloprotease belonging to the inverzincin family and participating in insulin cleavage. IDE was detected in most insulin-positive grade 3 carcinomas, indicating that it might be dysfunctional in these anaplastic tumors. IDE was equally present in the insulin-negative grade 2 carcinomas. Moreover, five grade 3 carcinomas and one grade 2 carcinoma displayed a loss of heterozygosity in the $10 \mathrm{q}$ chromosomal region harboring the IDE gene, but, despite these alterations, IDE was detected immunohistochemically, indicating a retention of the second allele. Compared to the expression of IDE in $92 \%$ of the tumors examined, only $57 \%$ of 21 normal breast specimens stained positively for IDE. In contrast to this increase in IDE-positive epithelial cells in breast cancer vs.
\end{abstract}

Correspondence to: Dr Razvan T. Radulescu, Klinische Forschergruppe der Frauenklinik der Technischen Universität München, Klinikum rechts der Isar, Ismaninger Str. 22, D-81675 München, Germany

E-mail: razvan.radulescu@lrz.tum.de

Key words: insulin, insulin-degrading enzyme, zinc metalloprotease, 10q23 genetic locus, immunohistochemistry, loss-of-heterozygosity analysis, immunoassay, normal breast, breast cancer, tumor marker normal breast, additional immunohistochemical analysis of 17 node-positive breast carcinomas and corresponding tumor-bearing lymph nodes showed that IDE expression decreases from primary tumor to lymph node metastasis. Altogether, this study represents the first demonstration of IDE in normal and neoplastic human mammary tissues. Our present report should also provide an experimental starting point towards exploring a potential role of IDE in the control of tumor progression.

\section{Introduction}

Breast cancer is the most prevalent neoplasia in women (1). Despite considerable progress over the past decade in the understanding of the pathogenesis of this disease, its molecular basis remains to be fully elucidated. Towards this goal, the longstanding investigation of various growth factors and their receptors has yielded important insights that have meanwhile led to initial therapeutic applications (2). Among these growth factors, insulin is of crucial importance. Insulin is able to promote the proliferation of human breast cancer cells $(3,4)$ and has been demonstrated to be present in human mammary tumors (5), specifically either in the cytoplasmic or the nuclear compartment (6). Elevated blood levels of insulin have been shown to be associated with an adverse prognosis in early-stage breast cancer (7).

One mechanism by which insulin conveys its growth regulatory signals is by interacting with the cell membranebound insulin receptor which in turn transmits the insulin signal further to the nucleus by means of intermediary protein cascades (8). A second pathway involves the internalization of insulin and its subsequent direct association with nuclear structures $(9,10)$. Meanwhile, evidence has emerged (11-14) suggesting that the internalized insulin achieves a major impact on growth by binding and thereby inactivating the nuclear tumor suppressor retinoblastoma protein (RB). 
Table I. Characterization of 23 breast carcinomas with regard to patient age, patient menopausal status, steroid hormone receptor status (classified according to the Remmele score on a scale from 0 to 12), HER2 status (on a scale from 0 to $3+$ ), the TNM classification as well as nuclear differentiation grade $(G)$ of the respective tumors.

\begin{tabular}{|c|c|c|c|c|c|c|c|c|c|}
\hline $\begin{array}{l}\text { Breast } \\
\text { tumor }\end{array}$ & $\begin{array}{l}\text { Patient } \\
\text { age }\end{array}$ & $\begin{array}{c}\text { Menopausal } \\
\text { status }\end{array}$ & $\begin{array}{c}\text { Estrogen } \\
\text { receptor status }\end{array}$ & $\begin{array}{l}\text { Progesterone } \\
\text { receptor status }\end{array}$ & $\begin{array}{l}\text { HER2 } \\
\text { status }\end{array}$ & $\mathrm{T}$ & $\mathrm{N}$ & $\mathrm{M}$ & $\mathrm{G}$ \\
\hline 1 & 44 & peri & $0 / 12$ & $9 / 12$ & - & $1 \mathrm{c}$ & 1 & 0 & 3 \\
\hline 2 & 65 & post & $12 / 12$ & $6 / 12$ & - & 2 & 0 & 0 & 3 \\
\hline 3 & 58 & post & $0 / 12$ & $0 / 12$ & - & 2 is & 1 & 0 & 3 \\
\hline 4 & 58 & post & $1 / 12$ & $3 / 12$ & - & $1 \mathrm{c}$ & 0 & 0 & 3 \\
\hline 5 & 64 & post & $2 / 12$ & $0 / 12$ & - & 2 & $1 \mathrm{c}$ & 0 & 3 \\
\hline 6 & 70 & post & $0 / 12$ & $0 / 12$ & + & 3 & 1 & 0 & 3 \\
\hline 7 & 53 & post & $0 / 12$ & $0 / 12$ & + & 2 & 0 & 0 & 3 \\
\hline 8 & 45 & n.a. & $0 / 12$ & $0 / 12$ & +++ & 2 & 0 & 0 & 3 \\
\hline 9 & 40 & pre & $0 / 12$ & $0 / 12$ & - & 2 & 0 & 0 & 3 \\
\hline 10 & 66 & post & $0 / 12$ & $0 / 12$ & - & $1 \mathrm{c}$ & 0 & 0 & 3 \\
\hline 11 & 82 & post & $0 / 12$ & $0 / 12$ & - & $2 b$ & $1 \mathrm{bi}$ & 0 & 3 \\
\hline 12 & 47 & n.a. & $0 / 12$ & $0 / 12$ & - & $1 \mathrm{c}$ & $1 \mathrm{bi}$ & $\mathrm{X}$ & 3 \\
\hline 13 & 45 & pre & $2 / 12$ & $12 / 12$ & +++ & $1 \mathrm{a}$ & 0 & 0 & 3 \\
\hline 14 & 58 & post & $0 / 12$ & $0 / 12$ & + & 2 & 0 & $\mathrm{x}$ & 3 \\
\hline 15 & 73 & post & $9 / 12$ & $9 / 12$ & - & 2 & 0 & 0 & 2 \\
\hline 16 & 58 & post & $12 / 12$ & $4 / 12$ & + & 2 & 0 & 0 & 2 \\
\hline 17 & 61 & post & $9 / 12$ & $0 / 12$ & ++ & 2 & 0 & 0 & 2 \\
\hline 18 & 55 & pre & $12 / 12$ & $12 / 12$ & - & $1 \mathrm{c}$ & 0 & 0 & 2 \\
\hline 19 & 65 & post & $6 / 12$ & $2 / 12$ & + & $1 \mathrm{c}$ & 0 & 0 & 2 \\
\hline 20 & 68 & post & $12 / 12$ & $12 / 12$ & - & $1 \mathrm{c}$ & $1 \mathrm{a}$ & 0 & 2 \\
\hline 21 & 71 & post & $9 / 12$ & $0 / 12$ & - & $1 \mathrm{c}$ & 0 & 0 & 2 \\
\hline 22 & 45 & pre & $12 / 12$ & $9 / 12$ & + & $1 \mathrm{c}$ & 0 & 0 & 2 \\
\hline 23 & 58 & n.a. & $0 / 12$ & $0 / 12$ & - & 2 & 0 & 0 & 1 \\
\hline
\end{tabular}

n.a, not available.

The intracellular, and most likely also the extracellular, turnover of insulin is tightly regulated by insulin-degrading enzyme (IDE), a both cytosolic and cell membrane-associated thiol- and zinc-dependent metalloprotease, which was cloned in 1988 (15). As a result of its proteolytic activity, IDE is able to interfere with the translocation of insulin from the cytosolic compartment to the nucleus and thus with its action in the nucleus (16). Specifically, cytosolic IDE reduces the amount of insulin translocating to the nucleus by cleaving it in a zinc ion-dependent manner since the inhibition of IDE by a zinc chelator increases the amount of nuclear insulin (16). Perhaps even more importantly, the long arm of chromosome 10 which harbors the human IDE gene (17) has been found to display deletions in many human tumors (18). In fact, it has been suggested that in some tumors with a $10 \mathrm{q}$ deletion or $10 \mathrm{q}$ loss of heterozygosity $(\mathrm{LOH})$, respectively, it is not the PTEN tumor suppressor which is affected, but an as yet unknown tumor suppressor $(19,20)$.

These considerations prompted us to investigate IDE both at the gene and the protein levels in human breast cancer. To this end, we performed immunohistochemical staining for IDE in normal vs. malignant mammary tissues, determined corresponding tissue insulin levels and analyzed the intratumoral IDE gene locus.

\section{Materials and methods}

Tissue collection. We studied tissue specimens of 21 normal mammary glands obtained from breast reduction surgery and of 23 primary breast carcinomas from patients treated at the Department of Gynecology and Obstetrics, Klinikum rechts der Isar, Munich, Germany, in the period 2001-2004, specifically 14 (poorly differentiated) grade 3 (G3) tumors, 8 (moderately differentiated) grade 2 (G2) tumors, and 1 (well-differentiated) grade 1 tumor (G1). In addition, tissue specimens of 17 node-positive G3 breast carcinomas and their corresponding tumor-bearing lymph nodes obtained from the same patients were investigated.

Determination of insulin by chemiluminescent immunoassay. Insulin was determined by means of a chemiluminescent immunoassay (CLIA) kit (Immulite ${ }^{\circledR}$, Diagnostic Product Corporation, CA, USA) specific for human insulin in both non-malignant breast and breast carcinoma tissue detergent extracts (1\% Triton X-100) which were prepared as previously described (21). According to the manufacturer's specifications, this CLIA kit has yielded a median insulin value of $8.9 \mu / \mathrm{IU}$ or $0.37 \mathrm{ng} / \mathrm{ml}$ and a lower $95 \%$ range of up to $28.4 \mu / \mathrm{IU}$ or $1.18 \mathrm{ng} / \mathrm{ml}$ for the serum of fasting healthy volunteers and possesses an analytical sensitivity of $2 \mu / \mathrm{IU}$ or $0.083 \mathrm{ng}$ 
Table II. Summary of results obtained for 23 breast carcinomas with regard to intratumoral insulin levels as determined by CLIA, IDE-IHC, and genetic analysis of the 10q23 chromosomal region.

\begin{tabular}{lcrc}
\hline $\begin{array}{l}\text { Breast tumor } \\
\text { specimen no. }\end{array}$ & $\begin{array}{c}\text { Intratumoral } \\
\text { insulin } \\
(\mathrm{ng} / \mathrm{mg} \text { protein })\end{array}$ & $\begin{array}{r}\text { IDE-IHC } \\
\text { staining }\end{array}$ & $\begin{array}{c}\text { Status of 10q23 } \\
\text { genetic locus }\end{array}$ \\
\end{tabular}

\begin{tabular}{|c|c|c|c|}
\hline 1 & 141.2 & + & $\mathrm{ROH}$ \\
\hline 2 & 108.7 & + & $\mathrm{LOH}$ \\
\hline 3 & 343.3 & + & $\mathrm{ROH}$ \\
\hline 4 & 93.1 & - & $\mathrm{ROH}$ \\
\hline 5 & 461.1 & - & $\mathrm{ROH}$ \\
\hline 6 & 63.4 & + & $\mathrm{ROH}$ \\
\hline 7 & b.d.l. & + & $\mathrm{LOH}$ \\
\hline 8 & 818.1 & + & $\mathrm{LOH}$ \\
\hline 9 & 225.3 & + & $\mathrm{ROH}$ \\
\hline 10 & 336.0 & + & $\mathrm{LOH}$ \\
\hline 11 & 372.4 & + & $\mathrm{ROH}$ \\
\hline 12 & 73.1 & + & $\mathrm{ROH}$ \\
\hline 13 & 72.0 & + & $\mathrm{LOH}$ \\
\hline 14 & 48.7 & + & $\mathrm{ROH}$ \\
\hline 15 & b.d.l. & + & $\mathrm{ROH}$ \\
\hline 16 & b.d.l. & + & $\mathrm{LOH}$ \\
\hline 17 & b.d.l. & + & $\mathrm{ROH}$ \\
\hline 18 & b.d.l. & + & $\mathrm{ROH}$ \\
\hline 19 & b.d.l. & + & $\mathrm{ROH}$ \\
\hline 20 & b.d.l. & + & $\mathrm{ROH}$ \\
\hline 21 & b.d.l. & ++ & $\mathrm{ROH}$ \\
\hline 22 & b.d.l. & + & $\mathrm{ROH}$ \\
\hline 23 & b.d.l. & + & $\mathrm{ROH}$ \\
\hline
\end{tabular}

b.d.1., below detection limit (of insulin CLIA assay). HC staining intensity was categorized as negative $(-)$, weak $(+)$, moderate $(++)$ or strong (+++); LOH, loss of heterozygosity; $\mathrm{ROH}$, retention of heterozygosity.

insulin/ml. Considering an average plasma protein level of approximately $75 \mathrm{mg} / \mathrm{ml}$ in healthy adults, the test's sensitivity for insulin is $0.001 \mathrm{ng}$ insulin/mg protein.

Immunohistochemical evaluation of IDE in normal and malignant breast tissue specimens. Formalin-fixed, paraffinembedded specimens (of normal kidneys, normal mammary glands, node-negative primary breast carcinomas as well as node-positive primary breast carcinomas and their corresponding tumor-bearing lymph nodes) were drawn at random from the archives of the Institute of Pathology of the Technical University of Munich (Germany). Immunohistochemical staining for IDE was performed as follows: first, the sections were deparaffinized and hydrated by passing them through xylene twice for $10 \mathrm{~min}$ and a graded series of ethanol from $100 \%$ ethanol twice for $5 \mathrm{~min}$ to $96 \%$ ethanol once for $5 \mathrm{~min}$ and finally to $70 \%$ ethanol for $5 \mathrm{~min}$. At this point, we did not recur to antigen retrieval by pressure cooking, given that we employed a biotin-based detection kit (cf. below), and in such an experimental setting pressure cooking, which is known to expose endogenous biotin molecules, could have led to falsely positive results, as shown before (22). After a 5-min washing step in Tris-buffered saline (TBS) at room temperature (RT) including buffer change, endogenous peroxidase activity was quenched by incubating the slides with a $3 \%$ hydrogen peroxide solution at RT for $15 \mathrm{~min}$. Subsequent to another 5-min washing step in TBS at RT including buffer change, the slides were incubated at $4^{\circ} \mathrm{C}$ overnight with a rabbit polyclonal antibody raised against recombinant full-length human IDE (23) that had been diluted 1:200 in antibody diluent (S2022, Dako, Hamburg, Germany). According to the manufacturer, this diluent has the property of reducing non-specific antibody binding. The procedure then resumed the next day with a 5-min washing in TBS at RT including buffer change. Subsequently, a biotinstreptavidin-peroxidase-based detection kit (K5003, Dako) was used whereby incubations with the biotinylated secondary antibody and the streptavidin-peroxidase were performed at RT for 20 min each with a 5-min washing step in between. After another identical washing step, the slides were incubated with the chromogen AEC (K3464, Dako) at RT for 3 min. After a final washing step, nuclei were counterstained in Mayer's acid hematoxylin for $10 \mathrm{sec}$, then the slides were rinsed under running tap water, transferred to distilled water and mounted with Kaiser's glycerol gelatin (Merck, Darmstadt, Germany). IDE-expressing normal kidney, specifically the tubules but not the glomeruli, served as a positive control.

LOH analysis of the intratumoral 10q23 region. DNA was extracted from tumor tissue specimens according to the manufacturer's instructions (QIA amp DNA Mini Kit, Qiagen) and subsequently analyzed using the polymerase chain reaction (PCR) method to evaluate whether these malignancies display a loss of heterozygosity (LOH) at the 10q23 genetic locus to which the human IDE gene has been mapped (24). To this end, the genetic markers D10S1173, D10S583 and D10S1755 closely flanking the human IDE gene were employed.

\section{Results}

Determination of insulin in breast carcinomas by chemiluminescent immunoassay. By means of a CLIA specific for human insulin, we determined the levels of insulin in detergent extracts prepared from 23 primary breast carcinoma tissues (Table I). Thirteen out of 14 (93\%) of the grade 3 neoplastic tissues displayed measurable insulin levels (Table II). By contrast, none of the grade $2 / 1$ tumors contained detectable insulin (Table II). Moreover, non-malignant mammary tissues (normal breast, mastopathy and mammary fibrosis) did not contain any detectable insulin either (data not shown).

IDE immunohistochemistry in normal and malignant human mammary glands. So far, there have been no reports in the literature on the presence of IDE in human tumor tissues vs. their normal counterparts. In order to address this as yet unexplored issue, we chose to perform immunohistochemistry for IDE in human breast cancer vs. normal mammary tissues. By use of a rabbit polyclonal antibody to IDE (23), we first 

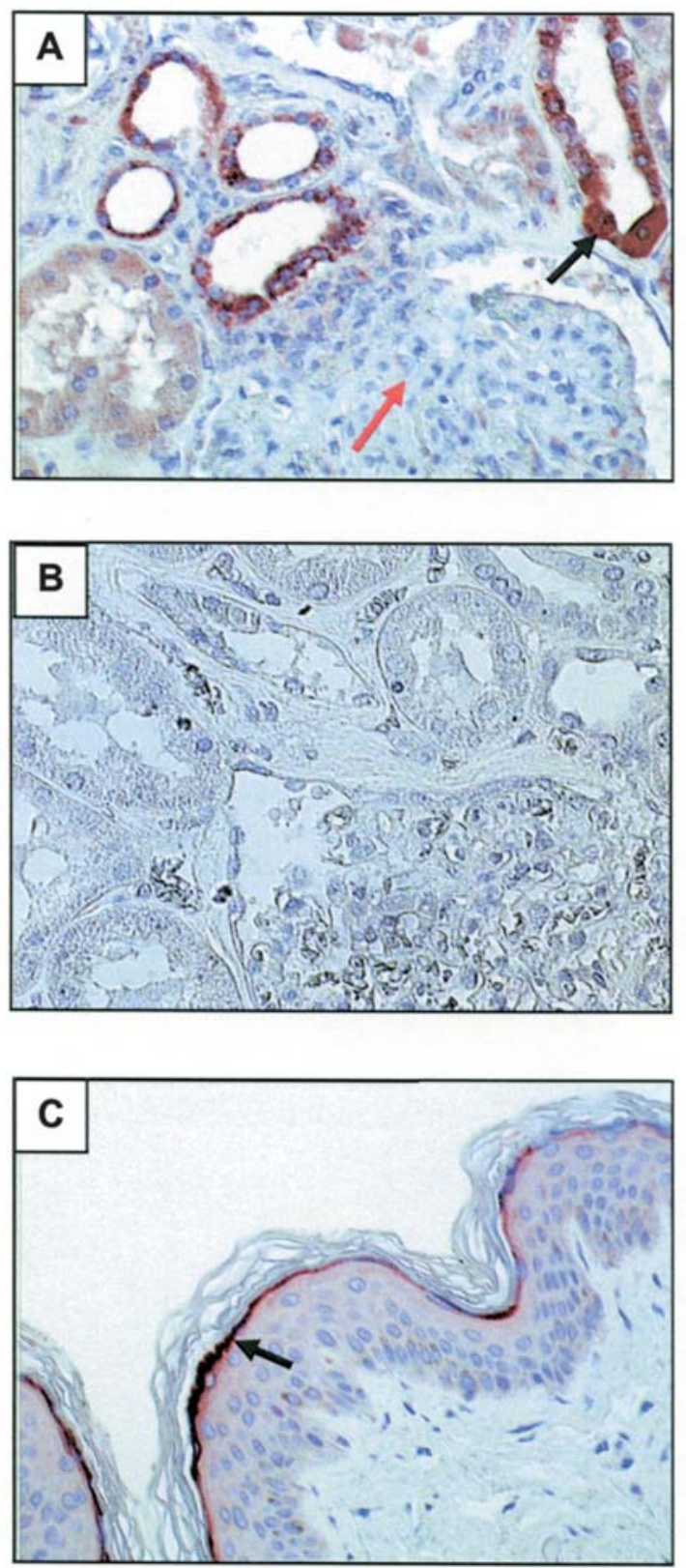

Figure 1. Immunohistochemical demonstration of IDE in formalin-fixed, paraffin-embedded normal kidney (A) whereby tubules were IDE-positive (black arrow) and glomeruli IDE-negative (red arrow) and in normal skin (C) with strong IDE staining in the stratum corneum (arrow) and moderate to weak IDE staining in the remaining skin layers. Incubating kidney sections without the primary IDE-directed antibody yielded the negative control (B). Magnification x200.

examined the expression pattern of IDE in 21 normal human breast tissues. Thereby, normal human kidney (Fig. 1A) and skin (Fig. 1C) sections were used for IDE-positive controls. Overall, we detected IDE only in the cytoplasmic compartment, yet not in the nucleus of epithelial cells (Fig. 2A and C). Moreover, we found a variable staining pattern whereby a focal epithelial expression of IDE was predominant (Fig. 2A). Of the 21 specimens investigated, 12 were IDE-positive $(57 \%)$ whereby the epithelial cell layer displayed staining heterogeneity with stained and unstained cells being interspersed (Fig. 2A and C). The remaining 9 specimens (43\%) were entirely IDE-negative (Fig. 2B).
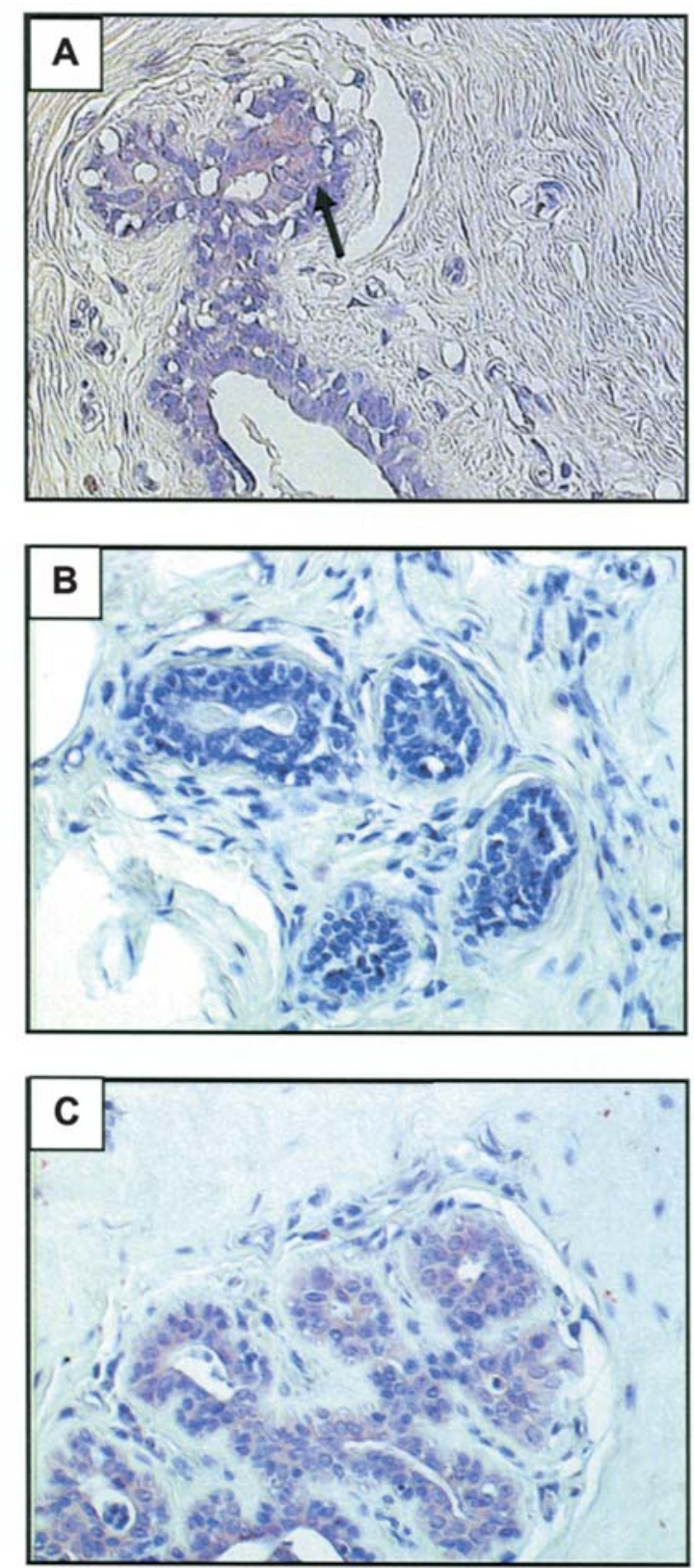

Figure 2. Immunohistochemical demonstration of IDE in formalin-fixed, paraffin-embedded normal breast (A and C) whereby focal expression (arrow) was seen most frequently (A). Some breast specimens, however, were entirely IDE-negative (B). Incubating corresponding normal mammary gland sections without the primary IDE-directed antibody yielded negative controls (data not shown). Magnification x200.

We then performed immunohistochemistry for IDE on sections from the 23 primary human breast cancer tissue specimens in which insulin had been determined (Tables I and II). In contrast to our findings in the normal breast tissues, the vast majority (22 out of 23 or $92 \%$ ) of these carcinomas were positive for cytoplasmic, yet not nuclear IDE (Fig. 3). Furthermore, IDE staining could be observed in all cells of the epithelial cell layer and, moreover, displayed a largely homogeneous staining pattern (Fig. 3). The remaining two grade 3 tumor specimens ( $8 \%$ ) were uniformly IDEnegative. Particularly illustrative for the difference in IDE staining between normal and malignant breast epithelia is one of the breast cancer specimens we have stained since it 

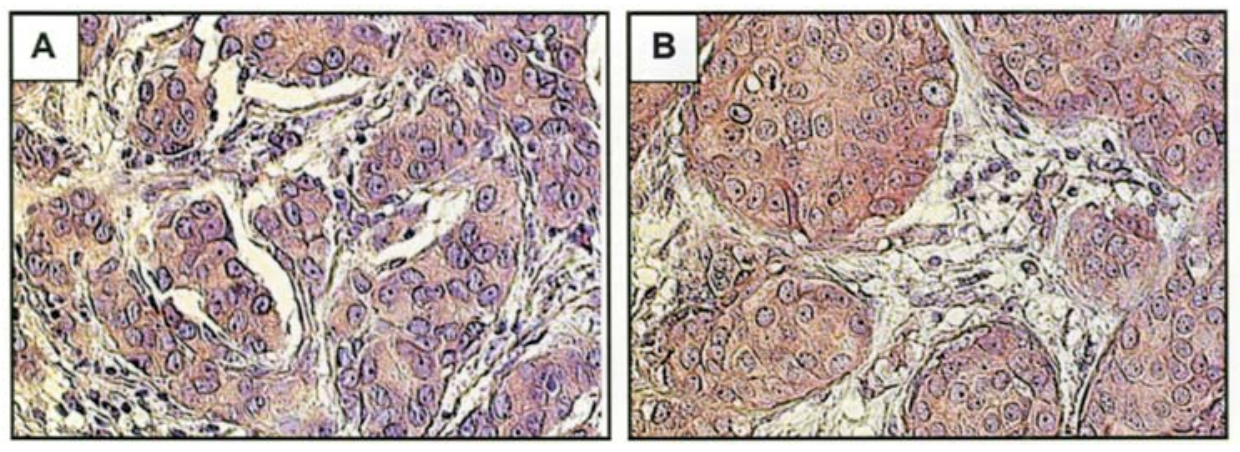

Figure 3. Immunohistochemical demonstration of IDE in formalin-fixed, paraffin-embedded primary breast cancer tissue specimens: IDE-positive grade 2 breast cancer (A) and IDE-positive grade 3 breast cancer (B). Incubating corresponding breast carcinoma sections without the primary IDE-directed antibody yielded negative controls (data not shown). Magnification x200.
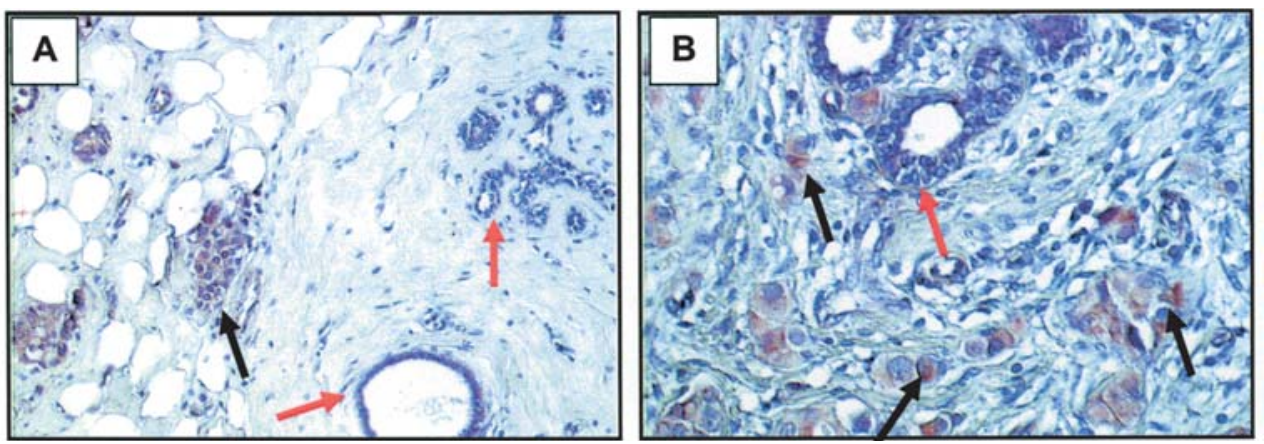

Figure 4. Immunohistochemical demonstration of IDE in a formalin-fixed, paraffin-embedded grade 3 breast carcinoma in which IDE-positive malignant cells (black arrow) are shown to be adjacent to an area of mostly IDE-negative (red arrow) normal breast duct epithelial cells. Incubating corresponding breast carcinoma sections without the primary IDE-directed antibody yielded negative controls (data not shown). Magnification: A, x100; B, x200.
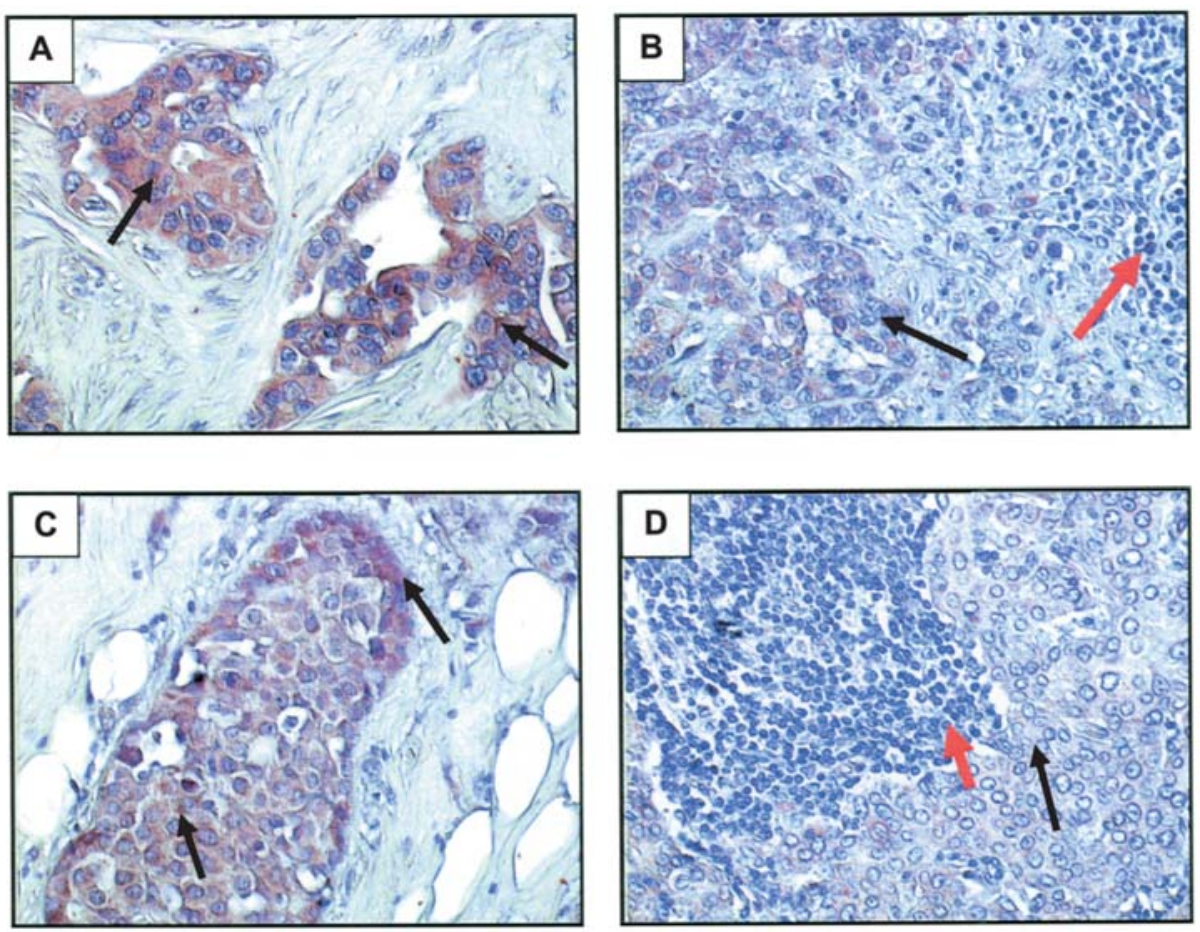

Figure 5. Immunohistochemical demonstration of IDE in node-positive breast cancer. Patient A (A and B): node-positive grade 3 breast cancer (A) whereby strong IDE staining is present in the perinuclear area (arrow) of some tumor cells, otherwise moderate IDE staining of the carcinoma cells, and a corresponding tumor-bearing lymph node (B) whereby tumor cells are weakly IDE-positive (black arrow) and the densely packed lymphocytes (red arrow) are recognized by their small, round and intensely blue stained nuclei. Magnification x200. Patient B (C and D): node-positive grade 3 breast cancer (C) whereby strong IDE staining is present in the perinuclear area (arrow) of some tumor cells and also at their invasive front (arrow), otherwise moderate IDE staining of the carcinoma cells. Corresponding tumor-bearing lymph node (D) whereby tumor cells are weakly IDE-positive (black arrow) and the densely packed lymphocytes (red arrow) are recognized by their small, round and intensely blue stained nuclei. Magnification x200. 
reveals the presence of IDE-positive cancer cells next to IDEnegative normal breast duct epithelia (Fig. 4). We also stained specimens from 17 node-positive breast carcinomas and their corresponding tumor-bearing lymph nodes. Thereby, we observed a tendency towards a decrease of IDE expression from primary tumor to tumor cells present in the corresponding lymph nodes (Fig. 5A vs. B and C vs. D).

Genetic analysis of the 10q23 locus. The above 23 tumors were also subjected to a PCR-based analysis of the 10q23 chromosomal locus to which the human IDE gene had previously been mapped in order to check for the presence of an LOH defect in this area. These samples were matched against tumor-free lymph nodes from the respective patients. Interestingly, we found that 5 of the $14(36 \%)$ grade 3 carcinomas displayed an $\mathrm{LOH}$ of the 10q23 genetic locus (Table II). By contrast, only 1 out of the 9 grade $2 / 1$ carcinomas (11\%) showed an $\mathrm{LOH}$ in the $10 \mathrm{q} 23$ chromosomal region (Table II).

\section{Discussion}

Zinc metalloproteases are an important class of proteolytic enzymes (25). Among these proteins, the family of zincins defined by the HEXXH amino acid motif comprises enzymes with various functions such as peptide bond-forming thermolysins important for the life cycle of bacteria, the blood pressure-controlling angiotensin-converting enzymes and matrixins/matrix metalloproteinases (MMPs). MMPs are intimately involved in the process of carcinogenesis, in particular in tumor invasion and progression (26). For instance, high expression levels of collagenase-1 (MMP-1) and stromelysin-1 (MMP-3) are known to be closely associated with cancer metastasis. By contrast, the distinct family of inverzincins is defined by the (inverted) HXXEH sequence motif (25) and mainly represented by IDE (insulysin), E. coli protease III/pitrilysin (15), NRD convertase/nardilysin (27), falcilysin (28), an inverzincin involved in the metabolism of the potentially lethal malaria parasite Plasmodium falciparum, and human metalloprotease 1 (29). IDE has so far been implicated in the pathogenesis of Alzheimer disease (30) and, moreover, been examined in connection with insulin metabolism in normal and transformed cells (31), but has not yet been linked to any state of malignancy.

Therefore, a major aim of the present study was to start investigating the inverzincin IDE in breast cancer tissue specimens. We have now found an increased presence of IDE protein in neoplastic breast tissues $(92 \%)$ vs. the normal mammary gland (57\%). The overexpression of IDE in breast cancer tissues observed by us could be a compensatory (defensive) cellular reaction, similar to the overexpression of the well-established tumor suppressors p16 (32), p73 $(33,34), \mathrm{nm} 23$ (35), p21 (36), and maspin (37) in malignant vs. normal tissues. As such, it is conceivable that IDE expression is upregulated in response to an increase in the level of insulin, both inside the cancer cell and (subsequent to insulin secretion) in the extracellular tumor microenvironment, during the transition from a normal to a malignant cellular phenotype. This explanation is in accordance with previous data demonstrating that insulin-mediated stimulation of the insulin receptor-associated signaling cascade leads to IDE up-regulation which in turn acts as a negative feedback mechanism to dampen this growth-promoting pathway by increasing insulin degradation (38). Interestingly, a compensatory role has previously been discussed for the maspin (39) and CTCF (40) candidate tumor suppressors.

This view is further supported by the insulin CLIA data obtained with our tissue extracts showing that, in keeping with a previous report on radioimmunoassay (RIA) determinations of insulin in normal and malignant breast tissues (5), the non-malignant breast tissues did not contain detectable insulin levels whereas the tumor tissues displayed measurable concentrations of this growth factor which were far above the assay's detection limit and may therefore explain the concomitant IDE overexpression we have observed by immunohistochemistry. Similar to these previous findings (5), the insulin-positive malignancies in our cohort had insulin levels which were considerably higher than those normally found in the serum of fasting healthy human individuals (cf. CLIA kit control values in Materials and methods), hence reflecting the measurement of genuine intratumoral insulin and thus not primarily of insulin stemming from the tumor's intravascular compartment.

More specifically, high levels of insulin were measured in all IDE-positive grade 3 breast carcinomas of our cohort except for one. Given the immunohistochemical presence of IDE in most of these cases, the concomitant presence of insulin suggests that IDE's capacity to degrade this growth factor was impaired in these tissues. This may have been due to high insulin levels surpassing IDE's enzymatic saturation or to posttranslational modifications of IDE interfering with its ability to degrade insulin. On the other hand, we could not detect any insulin in our grade 2/1 tumors. Since IDE staining was positive in all of these cases, it can be assumed that, in contrast to the above poorly differentiated grade 3 mammary neoplasias, these moderately differentiated grade 2 breast carcinomas as well as the well-differentiated grade 1 tumor contained functional IDE. Hence, our insulin CLIA data represent an interesting starting point for future studies that should address whether intratumoral insulin may serve as a novel cancer progression marker. Furthermore, we could not ascertain any relationship between the level of intratumoral insulin and the tumor's steroid hormone or HER2 receptor status.

Furthermore, we have detected several breast carcinomas with an $\mathrm{LOH}$ in the 10q23 chromosomal region to which the human IDE gene has been mapped (24). The LOH percentage was considerably higher in the poorly differentiated grade 3 mammary tumors $(36 \%)$ as compared to the better differentiated grade $2 / 1$ breast tumors $(11 \%)$, indicating that genetic defects in the portion of the 10q23 locus harboring the IDE gene may contribute to malignant progression. Our findings demonstrating IDE protein expression immunohistochemically despite the presence of an $\mathrm{LOH}$ in the 10q23 chromosomal region, specifically in five of the grade 3 breast carcinomas, could be due to a functional second allele, similar to the constellations found for the candidate tumor suppressor SIAH1 (41) and for point-mutated p53 (42).

In our investigated series of specimens, there were also two grade 3 human breast carcinomas which displayed an absence of the IDE protein, as determined immunohistochemically. 
This finding allows us to speculate that IDE may play a tumor suppressor role, at least in a small fraction of (poorly differentiated) breast cancers. This notion is reinforced by the observed decrease in IDE expression in node-positive breast cancer from primary tumor to (lymph node) metastasis. At this point, it is worth mentioning that our present immunohistochemical data on IDE in normal and malignant tissues parallel in an intriguing fashion those obtained with regard to the proapoptotic tumor suppressor Bax, the expression of which has equally been shown to increase from normal to tumor tissue and then to decrease from tumor to metastasis (43).

It should also be noted that the potential function of the IDE protease as a tumor suppressor suggested here adds to the emerging concept according to which some proteases or peptidases, respectively, can assume the roles of tumor suppressors (44-47). In this context, a parallel could also be drawn between IDE and the tumor suppressor PTEN. Similar to PTEN which prevents the nuclear translocation of cyclin D and thus the ensuing cyclin $\mathrm{D}$ binding and inactivation of $\mathrm{RB}$ (48), IDE may also keep the nuclear tumor suppressor RB in an active form by degrading insulin in the cytosol and consequently preventing it from translocating to the nucleus such that insulin cannot bind and inactivate RB.

Interestingly, we also found IDE expression in normal human skin whereby its predominant presence in the stratum corneum was reminiscent of the similar detection of another protease known to degrade insulin (49): human stratum corneum chymotryptic enzyme (SCCE), also named human tissue kallikrein 7 (hK7). Similar to IDE in our present study, hK7 has been shown to localize to the cytosol as well as to be overexpressed in cancer cells vs. normal cells (50). Furthermore, the differential IDE expression we found in the normal human kidney strikingly paralleled that of yet another protease: urokinase-type plasminogen activator which converts the pro-enzyme plasminogen into its proteolytically active form plasmin (51).

We have thus reported the first study on IDE in human (breast) malignancies as compared to normal tissues and thereby provided experimental clues to its putative tumor suppressor role. Future investigations will certainly have to examine in larger cohorts the validity of our present data. As such, it remains to be determined whether intratumoral IDE could also be used as a marker for breast cancer progression and thus add to the clinical value of lymph node staging, steroid hormone receptors and other established tumor biomarkers. Such a possibility appears likely not only in the light of the present findings, but also given the results of a previous study that has revealed that $\mathrm{P}-\mathrm{gp}$, a major protein mediating (anti-cancer) drug resistance, may bind and thereby inactivate IDE (52).

\section{Acknowledgements}

We thank Daniela Hellmann, Angelika Jahn and Edith Dürrmeyer for their excellent technical assistance. We are also grateful to Falko Fend, Yesim Gürbüz and Claus Werner Hann von Weyhern for helpful comments and suggestions in matters of histopathology. This study was supported in part by a grant from the Federal Institute for Drugs and Medical Devices, Bonn, Germany.

\section{References}

1. Boyle P and Ferlay J: Cancer incidence and mortality, 2004. Ann Oncol 16: 481-488, 2005.

2. Piccart-Gebhart MJ, Procter M, Leyland-Jones B, Goldhirsch A, Untch M, Smith I, Gianni L, Baselga J, Bell R, Jackisch C, Cameron D, Dowsett M, Barrios CH, Steger G, Huang C-S, Andersson M, Inbar M, Lichinitser M, Láng I, Nitz U, Iwata H, Thomssen C, Lohrisch C, Suter TM, Rüschoff J, Süto T, Greatorex V, Ward C, Straehle C, McFadden E, Dolci MS and Gelber RD: Trastuzumab after adjuvant chemotherapy in HER2positive breast cancer. N Engl J Med 353: 1659-1672, 2005.

3. Osborne CK, Bolan G, Monaco ME and Lippman ME: Hormone responsive human breast cancer in long-term tissue culture: effect of insulin. Proc Natl Acad Sci USA 73: 4536-4540, 1976.

4. Chappell J, Leitner JW, Solomon S, Golovchenko I, Goalstone ML and Draznin B: Effect of insulin on cell cycle progression in MCF-7 breast cancer cells. J Biol Chem 276: 38023-38028, 2001.

5. Castro A, Ziegels-Weissman J, Buschbaum P, Voigt W, Morales $\mathrm{A}$ and Nadji M: Immunochemical demonstration of immunoreactive insulin in human breast cancer. Res Commun Chem Pathol Pharmacol 29: 171-182, 1980.

6. Spring-Mills EJ, Stearns SB, Numann PJ and Smith PH: Immunocytochemical localization of insulin- and somatostatin-like material in human breast tumors. Life Sci 35: 185-190, 1984.

7. Goodwin PJ, Ennis M, Pritchard KI, Trudeau ME, Koo J, Madarnas J, Hartwick W, Hoffman B and Hood N: Fasting insulin and outcome in early-stage breast cancer: results of a prospective cohort study. J Clin Oncol 20: 42-51, 2002.

8. White MF: Insulin signaling in health and disease. Science 302 : 1710-1711, 2003.

9. Goldfine ID and Smith GJ: Binding of insulin to isolated nuclei. Proc Natl Acad Sci USA 73: 1427-1431, 1976.

10. Miller DS: Stimulation of RNA and protein synthesis by intracellular insulin. Science 240: 506-509, 1988.

11 Radulescu RT and Wendtner CM: Proposed interaction between insulin and retinoblastoma protein. J Mol Recognit 5: 133-137, 1992.

12. Radulescu RT, Bellitti MR, Ruvo M, Cassani G and Fassina G: Binding of the LXCXE insulin motif to a hexapeptide derived from retinoblastoma protein. Biochem Biophys Res Commun 206: 97-102, 1995.

13. Radulescu RT: From insulin, retinoblastoma protein and the insulin receptor to a new model on growth factor specificity: the nucleocrine pathway. J Endocrinol 146: 365-368, 1995.

14. Radulescu RT, Doklea E, Kehe K and Mückter H: Nuclear colocalization and complex formation of insulin with retinoblastoma protein in HepG2 human hepatoma cells. J Endocrinol 166: R1-R4, 2000.

15. Affholter JA, Fried VA and Roth RA: Human insulin-degrading enzyme shares structural and functional homologies with Escherichia coli protease III. Science 242: 1415-1418, 1988.

16. Harada S, Smith RM, Smith JA and Jarett L: Inhibition of insulin-degrading enzyme increases translocation of insulin to the nucleus in $\mathrm{H} 35$ rat hepatoma cells- evidence of a cytosolic pathway. Endocrinology 132: 2293-2298, 1993.

17. Affholter JA, Hsieh CL, Francke U and Roth RA: Insulindegrading enzyme: stable expression of the human complementary DNA, characterization of its protein product, and chromosomal mapping of the human and mouse genes. Mol Endocrinol 4: 1125-1135, 1990.

18. Qin L-X: Chromosomal aberrations related to metastasis of human solid tumors. World J Gastroenterol 8: 769-776, 2002.

19. Bostrom J, Cobbers JM, Wolter M, Tabatabai G, Weber RG, Lichter P, Collins VP and Reifenberger G: Mutation of the PTEN (MMAC1) tumor suppressor gene in a subset of glioblastomas but not in meningiomas with loss of chromosome arm 10q. Cancer Res 58: 29-33, 1998.

20. Yeh JJ, Marsh DJ, Zedenius J, Dwight T, Delbridge L, Robinson BG and Eng C: Fine-structure deletion mapping of 10q22-24 identifies regions of loss of heterozygosity and suggests that sporadic follicular thyroid adenomas and follicular thyroid carcinomas develop along distinct neoplastic pathways. Genes Chromosomes Cancer 26: 322-328, 1999.

21. Janicke F, Pache L, Schmitt M, Ulm K, Thomssen C, Prechtl A and Graeff $\mathrm{H}$ : Both the cytosols and detergent extracts of breast cancer tissues are suited to evaluate the prognostic impact of the urokinase-type plasminogen activator and its inhibitor, plasminogen activator inhibitor type 1. Cancer Res 54: 2527-2530, 1994. 
22. Kim SH, Jung KC, Shin YK, Lee KM, Park YS, Choi YL, Oh KI, Kim MK, Chung DH, Song HG and Park SH: The enhanced reactivity of endogenous biotin-like molecules by antigen retrieval procedures and signal amplification with tyramine. Histochem J 34: 97-103, 2002.

23. Chesneau V and Rosner MR: Functional human insulin-degrading enzyme can be expressed in bacteria. Protein Expr Purif 19: 91-98, 2000.

24. Espinosa R III, Lemons RS, Perlman RK, Kuo WL, Rosner MR and Le Beau MM: Localization of the gene encoding insulindegrading enzyme to human chromosome 10, bands q23-q25. Cytogenet Cell Genet 57: 184-186, 1991.

25. Hooper NM: Families of zinc metalloproteases. FEBS Lett 354: $1-6,1994$

26. Westermarck J and Kahari V-M: Regulation of matrix metalloproteinase expression in tumor invasion. FASEB J 13: 781-792, 1999.

27. Foulon T, Cadel S, Prat A, Chesneau V, Hospital V, Segretain D and Cohen P: NRD convertase and aminopeptidase B: two processing metallopeptidases with a selectivity for basic residues. Ann Endocrinol (Paris) 58: 357-364, 1997.

28. Eggleson KK, Duffin KL and Goldberg DE: Identification and characterization of falcilysin, a metallopeptidase involved in hemoglobin catabolism within the malaria parasite Plasmodium falciparum. J Biol Chem 274: 32411-32417, 1999.

29. Mzhavia N, Berman YL, Qian Y, Yan L and Devi LA: Cloning, expression and characterization of human metalloprotease 1: a novel member of the pitrilysin family of metalloendoproteases. DNA Cell Biol 18: 369-380, 1999.

30. Bertram L, Blacker D, Mullin K, Keeney D, Jones J, Basu S, Yhu S, McInnis MG, Go RCP, Vekrellis K, Selkoe DJ, Saunders AJ and Tanzi RE: Evidence for genetic linkage of Alzheimer's disease to chromosome 10q. Science 290: 2302-2303, 2000.

31. Chang LL, Stout LE, Wong WD, Buls JG, Rothenberger DA, Shier WT, Sorenson RL and Bai JPF: Immunohistochemical localization of insulin-degrading enzyme along the rat intestine, in the human colon adenocarcinoma cell line (Caco-2), and in human ileum. J Pharm Sci 86: 116-119, 1997.

32. Dai CY, Furth EE, Mick R, Koh J, Takayama T, Niitsu Y and Enders GH: p16(INK4a) expression begins early in human colon neoplasia and correlates inversely with markers of cell proliferation. Gastroenterology 119: 929-942, 2000.

33. Sun X-F: p73 overexpression is a prognostic factor in patients with colorectal adenocarcinoma. Clin Cancer Res 8: 165-170, 2002.

34. Guan M, Peng H-X, Yu B and Lu Y: p73 overexpression and angiogenesis in human colorectal carcinoma. Jpn J Clin Oncol 33: 215-220, 2003

35. Kapitanovic S, Cacev T, Berkovic M, Popovic-Hadzija M, Radosevic S, Seiwerth S, Spaventi S, Pavelic K and Spaventi R: $\mathrm{nm} 23-\mathrm{H} 1$ expression and loss of heterozygosity in colon adenocarcinoma. J Clin Pathol 57: 1312-1318, 2005.

36. Jung JM, Bruner JM, Ruan S, Langford LA, Kyritsis AP, Kobayashi T, Levin VA and Zhang W: Increased levels of p21WAF1/Cip1 in human brain tumors. Oncogene 11: 2021-2028, 1995.

37. Terashima M, Maesawa C, Oyama K, Ohtani S, Akiyama Y, Ogasawara S, Takagane A, Saito K, Masuda T, Kanzaki N, Matsuyama S, Hoshino Y, Kogure M, Gotoh, Shirane M and Mori K: Gene expression profiles in human gastric cancer: expression of maspin correlates with lymph node metastasis. $\mathrm{Br}$ J Cancer 92: 1130-1136, 2005.
38. Zhao L, Teter B, Morihara T, Lim GP, Ambegaokar SS, Ubeda OJ, Frautschy SA and Cole GM: Insulin-degrading enzyme as a downstream target of insulin receptor signaling cascade: implications for Alzheimer's disease intervention. J Neurosci 24: 11120-11126, 2004.

39. Kim DH, Yoon DS, Dooley WC, Nam ES, Ryu JW, Jung KC, Park HR, Sohn JH, Shin HS and Park YE: Association of maspin expression with the high histological grade and lymphocyte-rich stroma in early-stage breast cancer. Histopathology 42: 37-42, 2003.

40. Docquier F, Farrar D, D'Arcy V, Chernukhin I, Robinson AF, Loukinov D, Vatolin S, Pack S, Mckay A, Harris RA, Dorricott H, O'Hare MJ, Lobanenkov V and Klenova E: Heightened expression of CTCF in breast cancer cells is associated with resistance to apoptosis. Cancer Res 65: 5112-5122, 2005.

41. Medhioub M, Vaury C, Hamelin R and Thomas G: Lack of somatic mutation in the coding sequence of SIAH1 in tumors hemozygous for this candidate tumor suppressor gene. Int J Cancer 87: 794-797, 2000.

42. Singh S, Simon M, Meybohm I, Jantke I, Jonat W, Maass H and Goedde HW: Human breast cancer: frequent p53 allele loss and protein overexpression. Hum Genet 90: 635-640, 1993.

43. Jansson A and Sun XF: Bax expression decreases significantly from primary tumor to metastasis in colorectal cancer. J Clin Oncol 20: 811-816, 2002

44. Ramirez-Montagut T, Blachere NE, Sviderskaja EV, Bennett DC, Rettig WJ, Garin-Chesa P and Houghton AN: FAPalpha, a surface peptidase expressed during wound healing, is a tumor suppressor. Oncogene 23: 5435-5446, 2004.

45. Dai J, Shen R, Sumitomo M, Goldberg JS, Geng Y, Navarro D, $\mathrm{Xu}$ S, Koutcher JA, Garzotto M, Powell CT and Nanus DM: Tumor-suppressive effects of neutral endopeptidase in androgenindependent prostate cells. Clin Cancer Res 7: 1370-1377, 2001.

46. Goyal J, Smith KM, Cowan JM, Wazer DE, Lee SW and Band V: The role for NES1 serine protease as a novel tumor suppressor. Cancer Res 58: 4782-4786, 1998.

47. Sumitomo M, Iwase A, Zheng R, Navarro D, Kaminetzky D, Shen R, Georgescu MM and Nanus DM: Synergy in tumor suppression by direct interaction of neutral endopeptidase with PTEN. Cancer Cell 5: 67-78, 2004.

48. Radu A, Neubauer V, Akagi T, Hanafusa H and Georgescu MM PTEN induces cell cycle arrest by decreasing the level and nuclear localization of cyclin D1. Mol Cell Biol 23: 6139-6149, 2003.

49. Skytt A, Strömqvist M and Egelrud T: Primary substrate specificity of recombinant human stratum corneum chymotryptic enzyme. Biochem Biophys Res Commun 211: 586-589, 1995.

50. Santin AD, Cane S, Bellone S, Bignotti E, Palmieri M, De Las Casas LF, Roman JJ, Anfossi S, O'Brien T and Pecorelli S: The serine protease stratum corneum chymotryptic enzyme (kallikrein 7) is highly overexpressed in squamous cervical cancer cells. Gynecol Oncol 94: 283-288, 2004

51. Wagner SN, Atkinson MJ, Wagner C, Höfler H, Schmitt M and Wilhelm O: Sites of urokinase-type plasminogen activator expression and distribution of its receptor in the normal human kidney. Histochem Cell Biol 105: 53-60, 1996.

52. Radulescu RT, Zhang BY, Wilmanns W and Nüssler V: Human P-glycoprotein/Mdr1-gene product: surprising potential for nuclear localization and coupling to intracellular growth factor signalling. In: Acute Leukemias VII-Experimental Approaches and Novel Therapies. Springer-Verlag Berlin Heidelberg, pp454-455, 1998. 